\title{
The Role of Cultural Capital in Higher Education Access and Institutional Choice
}

IvA KošUTiĆ ${ }^{1}$

$\approx$ This paper aims to explore social inequalities in school achievement and educational decision-making of the final-year students of secondary schools in the City of Zagreb and Zagreb County, Croatia $(\mathrm{N}=534)$. The theoretical framework of the paper was Bourdieu's theory of cultural and social reproduction (1977a). The main objectives were an analysis of the association between the students' cultural capital and their school achievement and analyses of the predictive power of the cultural capital theory in the context of educational decisions in the transition to tertiary education. In the analysis of school achievement, sequential multiple regression analysis was used, while in the analyses of educational decisions logistic regression analyses were performed (binary and multinomial logistic regression). The results indicated that cultural capital had statistically significant correlation with school performance. Among the cultural capital indicators, statistically significant predictors of the probability of the intention to enrol into vocational higher education were the material dimension of cultural capital and naturalness of higher education aspirations of students. For the prediction of the probability of intention to enrol in university, significant predictors were embodied cultural capital, the naturalness of higher education aspirations of students, and father's educational level. The study results on a selected sample of graduates tend to support Bourdieu's theory of cultural reproduction through education.

Keywords: cultural capital; educational decisions; educational inequality; school achievement 


\section{Vloga kulturnega kapitala pri dostopu do visokošolske izobrazbe in institucionalne izbire}

Iva Košutić

$\propto$ Namen prispevka je raziskati socialne neenakosti v šolskih dosežkih in pri sprejemu izobraževalnih odločitev dijakov zadnjega letnika srednje šole v mestu Zagreb in občini Zagreb $(\mathrm{N}=534)$. Teoretski okvir prispevka predstavlja Bourdieuejeva teorija kulturne in socialne reprodukcije (1977a). Glavna cilja sta bila analiza povezanosti med kulturnim kapitalom dijakov in njihovim šolskim uspehom ter analiza napovedne moči teorije kulturnega kapitala v kontekstu izobraževalnih odločitev v prehodu na terciarno raven izobraževanja. Pri analizi šolskih dosežkov je bila uporabljena analiza sekvenčne multiple regresije, medtem ko je bila pri analizi izobraževalnih odločitev uporabljena logistična regresija (binarna in multinominalna logistična regresija). Rezultati so pokazali, da je kulturni kapital statistično pomembno povezan s šolsko uspešnostjo. Med indikatorji kulturnega kapitala so kot statistično pomembni napovedniki verjetnosti namere za vpis $\mathrm{v}$ poklicno srednješolsko izobraževanje predstavljeni opredmetena dimenzija kulturnega kapitala in aspiracije dijakov. Pri napovedovanju verjetnosti namere za vpis na univerzo so bili pomembni napovedniki utelešen kulturni kapital, srednješolske aspiracije dijakov in izobrazbena raven očeta. Rezultati študije na izbranem vzorcu diplomantov podpirajo Bourdieujevo teorijo kulturne reprodukcije v polju izobraževanja.

Ključne besede: kulturni kapital, izobraževalne odločitve, izobraževalna neenakost, šolski dosežki 


\section{Introduction}

Educational inequalities have long been the interest of sociologists of education as numerous studies continuously emphasise the association between students' social background and their educational performance. The period after World War II was marked by the need to 'change the elitist nature of universities' (Guri-Rosenblit, Sebkova, \& Teichler, 2007, p. 1) by widening the access to students from all social strata, with expectations that wider access would eventually lead to greater opportunity for social mobility. This need stemmed from the fact that industry and job demands had changed, requiring more educated individuals on suitable positions, but also from the growing conscience that education is a human right: 'Technical and professional education shall be made generally available, and higher education shall be equally accessible to all on the basis of merit' (Universal Declaration of Human Rights, 1948). In line with international trends, data on the massification of higher education in Croatia from 1951 to 2014 show that the number of students had grown more than five-fold, which testifies to its 'exponential growth' (Baranović, 2015, p. 23). However, the widening of higher education and its massification and universalisation (Trow, 1974) decades ago did not substantially weaken the strength of association between family's social origin and educational pathways of the children (Karabel \& Halsey, 1977; Van de Werfhorst, Sullivan \& Cheung, 2003). Research shows that, despite various educational reforms, children from upper classes generally perform better in school and more frequently choose tertiary education than children from less privileged backgrounds do (Boalt 1947, Harnqvist 1958, Jencks \& Riesman 1968, in Erikson, 2007; Erikson et al., 2005). An OECD report (2010) highlights the importance of parents' socio-economic status (SES) for educational performance of the children in all OECD countries and emphasises the fact that inequalities in secondary education translate into inequalities in tertiary education, and later in inequalities in occupation and income. Eurostat's Intergenerational transmission of disadvantage statistics (2013) emphasises the association of parents' and children's levels of education.

The Eurostudent report for Croatia (2011) showed similar trends: students whose parents have completed less than four years of secondary education are underrepresented in tertiary education. A comparative international Eurostudent report (2011) thus labels the Croatian higher education system as socially exclusive, characterised by 'high level of underrepresentation of students from low education backgrounds and a high level of overrepresentation of students from high education backgrounds' (Eurostudent, 2011, p. 2). The importance of the social dimension in higher education on a European level 
is emphasised in various documents (see Europe 2020, 2010; Leuven Communiqué, 2009; London Communiqué, 2007; Prague Communiqué, 2001) and recently in Croatia in the national Strategy of Science, Education and Technology (2014) whose aim is, among others, to accomplish 'general accessibility of higher education in order to ensure socially equitable system' (2014, p. 93).

Despite international trends in research on educational inequalities, there has been a lack of empirical sociological research of such phenomena in Croatia, with even fewer studies exploring the potential mechanisms behind educational inequalities. Babarović, Burušić and Šakić (2009), Burušić, Babarović and Marković (2010), Jokić and Ristić Dedić (2010) examine, among other factors, the relationship between family background and school performance of elementary school pupils, Gregurović and Kuti (2010), Matković (2010), Puzić, Gregurović and Košutić (2016) on secondary school students, and Puzić, Doolan and Dolenec (2006) and Doolan (2009) amongst university students. In order to investigate the educational inequalities in a Croatian setting, this paper ${ }^{2}$ follows a critical perspective and examines the inequalities in school performance and access to higher education for students of different social origin using Bourdieu's cultural reproduction theory (1977a). This study had also contributed to the collection of primary data on the topic, which has been approached, thus far, in Croatia mainly through secondary data.

\section{Theory of Cultural and Social Reproduction}

Bourdieu's theory of social reproduction (1977a) focuses on the cultural aspects of social inequality, investigating which social mechanisms create and perpetuate social reproduction and enable the maintenance of a classed society. According to Bourdieu (1973, 1977a, 1986, 1990), the most important mechanism of social reproduction is the reproduction and legitimisation of social inequalities via the reproduction of the culture of the dominant classes. Bourdieu acknowledges the importance of the obvious mechanisms of social reproduction, maintained through the transfer of economic inequality, but he stressed the importance of a less obvious and, therefore, more significant mechanism of maintaining social inequalities: the reproduction of the culture of the dominant classes. For Bourdieu (1977a), the educational system is the key factor in legitimising existing social structures and class relations, because it is based on standards and knowledge of the upper classes. The educational system, which

2 The data for this paper were collected during the research project 'Social identities, higher education access and course choice' funded by the Croatian Science Foundation (project No. 09.01/404). 
is characterised by 'apparently neutral attitude' (Bourdieu, 1977a), reflects the existing power relations in wider society and favours children familiar with the dominant culture: 'This consists mainly of linguistic and cultural competence and that relationship of familiarity with culture which can only be produced by family upbringing when it transmits the dominant culture.' (Bourdieu 1977a, p. 494). This means that the school system is not compensating for the lack of such competencies to the children from less privileged family backgrounds, who experience schools as unnatural and intimidating environments. As a consequence, pupils of lower social origin adapt with more difficulty to the school culture, have generally lower school performance and lower educational and professional aspirations. The educational system is, therefore, an important factor in maintaining social inequalities, as students from educationally, financially, and socially privileged families achieve higher educational and professional success and thereby reproduce patterns of social stratification and retain their inherited positions of power. Goldthorpe notes that social reproduction is thus 'doubly guaranteed' (2007, p. 11): by transmission of family's capital to children and by passive role of an educational system that does not enable social transformation.

Different family class positions form different systems of thought and reasoning, a specific way of thinking, which Bourdieu refers to as 'habitus'. For Bourdieu, habitus is 'a system of lasting, transposable dispositions which, integrating past experiences, functions at every moment as a matrix of perceptions, appreciations, and actions' (Bourdieu 1977b, p. 82-83). Habitus is a way of understanding the world, an individual's 'mental structure' (Bourdieu, 1989, p. 18), which contributes to social reproduction. The importance of the habitus primarily attained in the family is in the fact that it forms a basis for acceptance and comprehension of the messages in the classroom. Thus, the family habitus affects children's predispositions towards school and the affinity to invest time, effort, and money to preserve the family's capital and social status.

Bourdieu differentiates several types of capital, all valuable in the educational system and vital for understanding social inequalities in general: economic, social and cultural capital (Bourdieu, 1997). Cultural capital is the most useful form of capital in the educational system (Dumais, 2006). It is a form of symbolic power that can be, via education, transformed into economic capital (Bourdieu, 1997; Swartz, 1997). According to Bourdieu (1997), cultural capital exists in three forms: as embodied (incorporated in person: linguistic competences, cultural affinities, taste), objectified (material form of cultural capital: possession of cultural goods such as books, paintings, works of art, etc.) and institutionalised (educational qualifications). For upper-class children, the 
transmission of cultural capital starts immediately, in family, and is naturally followed in schools (Bourdieu, 1986). Teachers recognise and reward the possession of cultural capital in subtle ways; they communicate better with children who possess more cultural capital and even 'perceive them as more intelligent or gifted than students who lack cultural capital' (DiMaggio 1982, p. 190). In contrast, children from less privileged family backgrounds lack cultural capital at home and are thus in an inferior position in the educational system.

For Bourdieu (1997), cultural capital can be converted into economic capital only through the educational system, which confirms the possession of cultural capital in the form of educational qualifications. These qualifications then potentially translate into economic capital. Convertibility is, therefore, the basis of strategies to ensure the reproduction of capital over time (Bourdieu, 1997, p. 54). Due to its significance for the educational system, this paper focuses on Bourdieu's concept of cultural capital as a key factor in the transmission of social inequalities.

\section{Cultural Capital in Educational Research}

Bourdieu did not precisely define nor limit the cultural capital concept, although he did make some references to specific cultural practices (such as visits to theatres, concerts, and museums) and the possession of cultural goods (Bourdieu, 1984). For that fact, in empirical studies of educational inequality, cultural capital is operationalised in various ways. DiMaggio's (1982) work on the association between American high school students' cultural capital and their academic performance is often cited in literature as one of the most influential studies on this topic (Kingston, 2001; Lareau \& Weininger, 2003). Starting from Weber's (1968) notion of 'status culture', DiMaggio operationalised cultural capital as a participation in the elite status culture, in 'art, classical music and literature' (DiMaggio, 1982, p. 191). DiMaggio's analyses indicated a positive association between students' possession of cultural capital and school grades, with especially strong impact on grades in nontechnical subjects. However, the impact of cultural capital was found to be most significant for the males from lower social origin, which was interpreted as a proof of the cultural mobility model (stating that cultural capital affects educational performance regardless of social origin; its possession is not tied only to dominant classes). That finding was supported by Kalmijn and Kraaykamp's (1996) study that showed that cultural capital can compensate for disadvantages related to social origin. Although DiMaggio's operationalisation of cultural capital as participation in high-class activities is among most frequently used in quantitative research (Barone, 2006), some 
researchers extended the concept of cultural capital on students' and family's reading practices. On a representative sample of 15 -year olds in the Netherlands, De Graaf (1986) found a statistically significant effect of parents' reading practices on their children's educational performance, regardless of the socioeconomic status of the family. The importance of reading practices for school attainment was supported by De Graaf's (1988) study on a German sample of high school students and by a study of De Graaf et al. (2000) on a Netherlands sample. Both studies stress the importance of family's reading climate for the development of linguistic and cognitive competencies that affect school success and that can, to a certain extent, compensate for a low socioeconomic status of the family.

The mentioned indicators referring to the cultural practices of students and their families facilitate the attainment of embodied form of cultural capital, while some studies also include the operationalisations of cultural capital indicators of its material dimension. This refers to possession of cultural goods and objects of art (books, dictionaries, musical instruments, etc.) whose disposition at home could be helpful to children in educational process (Barone, 2006; Jæger, 2009, 2011; Sullivan, 2000; Teachman, 1987). These studies indicated that the possession of these potential educational resources is associated with children's school success.

A number of studies of cultural capital in education have addressed the interactive aspects of the family environment (Barone 2006; Downey, 1995; Jaeger, 2009, 2011; Tramonte \& Willms, 2010), and school environment, that is the interaction of students and parents with teachers and other relevant stakeholders of the educational process (Lareau \& Horvat, 1999). In the first case, the specific family patterns of interaction and communication through which parents transmit their cultural capital (as part of a family habitus) to children were examined; in the second case, studies examined the ways in which students and their parents use cultural capital in order to obtain preferential treatment and accomplish school success (Jæger, 2009).

The previously discussed studies mainly confirm the importance of the effect of the students' and family's cultural capital on the educational achievement of children, even in different social and educational contexts. Following similar research, this article analyses the elements of embodied and objectified cultural capital of parents and students and some aspects of their interactions.

\section{Research Objectives and Hypotheses}

The main objectives of this paper were the analysis of the association between the students' cultural capital and their school achievement, as well as 
the analysis of the predictive power of the cultural capital theory in the context of educational decisions in the transition to tertiary education. In line with the set objectives, the following hypotheses were formulated:

Hypothesis 1. The possession of cultural capital is positively related to students' school achievement. The basis of Bourdieu's (1977) theory is the notion that the educational system rewards the possession of cultural capital and converts it into educational success. Although numerous studies (DiMaggio, 1982; De Graaf, 1986, 1988; De Graaf et al., 200o; Flere et al. 2010; Kalmijn and Kraaykamp, 1996; Kingston, 2001; Sullivan, 200o) indicate that the possession of cultural capital is associated with educational achievement, there is a lack of detailed research in a Croatian setting. Thus, the hypothesis was formulated in accordance with the previous international findings.

Hypothesis 2. The students with greater possessions of cultural capital are more likely intend to continue to tertiary education at university than students with lower levels of cultural capital do.

Hypothesis 3. The students with greater possessions of cultural capital are less likely intend to continue to tertiary education at polytechnic schools than students with lower levels of cultural capital do. These two hypotheses are based on Bourdieu's (1977) assertion that the continuation of schooling is the natural and logical choice for students in greater possessions of cultural capital, who often come from privileged social backgrounds. The decision to continue education at university (prestigious institution) provides continuity in maintaining the family's high social status (cultural reproduction through education leads to social reproduction).

\section{Methods}

\section{Sample}

The study was conducted on $\mathrm{N}=534$ students in their final year of high school (age of the students was from sixteen to eighteen years). The sample included $5 \%$ of the population of students in the finale school year in the City of Zagreb and Zagreb County, ${ }^{3}$ which included 18 schools in Zagreb (427 stu-

3 Zagreb County is the surrounding area of the capital city Zagreb. It has a population of 317,642 people situated in nine cities, 25 municipalities and 697 settlements. The region was chosen for the sampling to achieve greater variability of the SES and cultural capital; Zagreb County has fewer adults with finished higher education than the City of Zagreb does (12.89\% vs. $28.98 \%$ ), relies more on agriculture and has a $22 \%$ lower average monthly net income per capita than the City of Zagreb does (Croatian Bureau of Statistics - Census, 2011). 
dents) and five schools (107) in Zagreb County, representative with regard to gender and school type (three- or four-year vocational school, gymnasium (academic-oriented secondary school)). The questionnaire survey was conducted in schools, during one school hour. Only one class of the students (randomly selected by the school personnel) in each school participated in the survey. The survey was anonymous and included the informed consent of the students.

\section{Measures}

\section{Dependent variables}

School achievement - This variable included the students' general gradepoint averages at the end of their previous school year (open answer).

Aspirations for higher education - Students' intention to proceed or not to proceed to tertiary education after secondary school. The variable had two categories - 'I intend to proceed to tertiary education' (1) and 'I do not intend to proceed to tertiary education' (2).

Likelihood of continuing education at university - students reported the likelihood of their attempting to continue education at the university/academy level on a scale from 1 ('definitely will not') to 5 ('definitely will'). After inspection of the distribution of answers, the variable was recoded into three categories: 'Definitely not/probably not/I am not sure' (1), 'Probably will' (2) and 'Definitely will' (3).

Likelihood of continuing education at polytechnic school or professional higher education institution - students reported on a scale from 1 ('definitely will not') to 5 ('definitely will') try to continue education at the non-university tertiary level. After the inspection of the distribution of answers, the variable was recoded into two categories: 'Definitely not/probably not/I am not sure' (1) and 'Probably will/definitely will' (2).

\section{Independent variables}

Secondary school type - The students were asked what type of secondary school they attend (three-year vocational school, four-year vocational school or gymnasium). In the regression models, the variable was recoded into a dummy variable for each school type.

Parents' cultural capital - The variable was created as a composite index containing six items representing the embodied forms of cultural capital: parents' frequency of museums/art galleries visits, frequency of theatre visits, frequency of opera/ballet/classical concerts visits, frequency of reading prose, frequency of reading non-fiction books, and frequency of participation in 
educational programmes/courses. Students reported on a scale from 1 ('never') to 5 ('very often'). Cronbach's $\alpha$ for the index was 0.81 .

Parental education - This variable was based on the students' answers on their parents' highest educational level (both mothers' and fathers'). The variables had five categories: (un)finished elementary school (1), finished three-year vocational school (2), finished four-year high school (vocational or gymnasium) (3), finished non-university tertiary education (4) and finished university/ doctoral degree (5).

Transfer of cultural capital - The variable was created as a composite index containing three items measuring the parents' support to students. Students reported on a scale from 1 ('strongly disagree') to 5 ('strongly agree') regarding the following statements: 'My parents are interested in what I do in school', 'My parents help me with school tasks when needed' and 'My parents encourage me to continue education'. Cronbach's a for the index was 0.64 .

Students' material cultural capital - This variable was created as a composite index containing two variables: The number of books in the household (students' estimates on the number of books in their household, ranging from 1 ('o-10 books'), to 6 ('more than 500 books') and Index of educational resources (sum of students' positive answers on the possession of computer, own room, study table, books, internet connection, dictionaries, classic books, books in foreign languages, works of art, and music CDs).

Students' embodied cultural capital - This variable was created as a composite index containing three variables: Students' cultural practices (a composite variable of five items- frequency of: museums/art galleries, theatre, opera/ballet/classical concerts, cinema and pop/rock concerts visits. Students reported on a scale from 1 ('never') to 4 ('more than four times a year'), Participation in extracurricular activities (a composite variable consisting of four items: drama group, ballet/dance, choir and music school attendance) and Students' reading practices (a composite variable consisting of three items: frequency of students' reading non-fiction books, popular-science/culture magazines and poetry/ prose). Students reported on a scale from 1 ('never/almost never') to 5 ('several times a week/every day').

Naturalness of higher education ${ }^{4}$ - According to Bourdieu $(1977,1997)$, for the students of privileged social backgrounds, the completion of higher education is an implied, natural sequence of events. To test the student's understanding of the naturalness of study, a categorical variable was constructed. The students chose one out of three possible choices: 'It implies to me that I will

4 The variable name was shortened from the phrase 'naturalness of higher education aspirations of students'. 
enrol into higher education', 'It implies to me that I will not enrol into higher education', and 'I cannot tell if it implies or not to me that I will enrol into higher education' (student does not infer either outcome). This variable was recoded into dummy variables in the regression models.

Socio-economic status of the family (SES) - This variable was created as a composite index containing four variables: owning a computers/cars/ real estate, financial position of the family, social position of the family, and ISEI. Owning a computers/cars/real estate referred to possessions of these goods in the family; financial position of the family referred to students' subjective assessment of the family's financial situation; social position of the family referred to students' subjective assessment of the family's social status (on the scale from 1 ('lowest position') to 10 ('highest position')). The ISEI (International SocioEconomic Index of occupational status) was created on the basis of students' answers about the employment of their parents and descriptions of the job they do. The open answers about parents' jobs and employment were first coded into the International Standard Classification of Occupations (ISCO) codes (ILO $1990)$, then transformed into the ISEI using IBM SPSS Statistics syntax from Ganzeboom (2013). The ISEI included highest ISEI of the parent (mother's or father's).

\section{Statistical procedures}

In the first step, bivariate (Pearson) correlations between dependent and independent variables were analysed. In the analysis of school achievement, sequential multiple regression analysis was used, while in the analyses of educational decisions logistic regression analyses were performed (binary and multinomial logistic regression).

\section{Results}

Table 1 displays correlations between school performance and explanatory variables (except categorical variables) used in the analysis. The strongest association was between the variables of parents' cultural capital and family SES. Other significantly associated variables were the parents' and students' cultural capital, as well as the parents' cultural capital and the transfer of cultural capital. Students' embodied cultural capital was significantly associated with the family SES and school achievement, while school achievement was significantly associated with the family SES, but not with the parents' cultural capital and the transmission of cultural capital. 
Table 1. Correlations between school performance and explanatory variables

\begin{tabular}{|c|c|c|c|c|c|}
\hline & $\begin{array}{c}\text { Parents' } \\
\text { cultural capital }\end{array}$ & $\begin{array}{l}\text { Students' embodied } \\
\text { cultural capital }\end{array}$ & $\begin{array}{l}\text { Family } \\
\text { SES }\end{array}$ & $\begin{array}{c}\text { Transfer of } \\
\text { cultural capital }\end{array}$ & $\begin{array}{c}\text { School } \\
\text { achievement }\end{array}$ \\
\hline $\begin{array}{l}\text { Parents' cultural } \\
\text { capital }\end{array}$ & 1 & $0.42^{* *}$ & $0.57^{* *}$ & $0.22^{* *}$ & 0.80 \\
\hline $\begin{array}{l}\text { Students' embodied } \\
\text { cultural capital }\end{array}$ & & 1 & $0.24^{* *}$ & 0.73 & $0.15^{* *}$ \\
\hline Family SES & & & 1 & $0.11^{* *}$ & $0.12 * *$ \\
\hline $\begin{array}{l}\text { Transfer of cultural } \\
\text { capital }\end{array}$ & & & & 1 & 0.61 \\
\hline School achievement & & & & & 1 \\
\hline
\end{tabular}

${ }^{* *} p<0.01$

To provide a more detailed insight of the impact of the explanatory variables on the selected educational outcomes, multivariate analyses predicting school performance and educational decisions were conducted. Table 2 presents five regression models with school achievement as an independent variable.

Table 2. Multiple regression models for predicting school achievement

\begin{tabular}{|c|c|c|c|c|c|c|c|c|c|c|}
\hline & \multicolumn{2}{|c|}{ Model 1} & \multicolumn{2}{|c|}{ Model 2} & \multicolumn{2}{|c|}{ Model 3} & \multicolumn{2}{|c|}{ Model 4} & \multicolumn{2}{|c|}{ Model 5} \\
\hline & Beta & $p$ & Beta & $p$ & Beta & $p$ & Beta & $p$ & Beta & $p$ \\
\hline Gender $(0=M, 1=F)$ & 0.19 & 0.00 & 0.20 & 0.00 & 0.20 & 0.00 & 0.20 & 0.00 & 0.18 & 0.00 \\
\hline $\begin{array}{l}\text { 3-year vocational } \\
\text { school* }\end{array}$ & -0.32 & 0.00 & -0.31 & 0.00 & -0.28 & 0.00 & -0.28 & 0.00 & -0.17 & 0.00 \\
\hline $\begin{array}{l}\text { 4-year vocational } \\
\text { school }\end{array}$ & -0.20 & 0.00 & -0.20 & 0.00 & -0.17 & 0.00 & -0.18 & 0.00 & -0.15 & 0.00 \\
\hline $\begin{array}{l}\text { Mother's educa- } \\
\text { tion }\end{array}$ & & & -0.03 & 0.54 & -0.06 & 0.23 & -0.05 & 0.37 & -0.06 & 0.24 \\
\hline Father's education & & & 0.03 & 0.50 & -0.00 & 0.94 & 0.00 & 0.97 & 0.01 & 0.90 \\
\hline Family SES & & & & & 0.02 & 0.73 & 0.03 & 0.60 & 0.04 & 0.47 \\
\hline $\begin{array}{l}\text { Students' material } \\
\text { cultural capital }\end{array}$ & & & & & 0.15 & 0.00 & 0.17 & 0.00 & 0.14 & 0.01 \\
\hline $\begin{array}{l}\text { Parents' cultural } \\
\text { capital }\end{array}$ & & & & & & & -0.08 & 0.14 & -0.08 & 0.16 \\
\hline $\begin{array}{l}\text { Transfer of cul- } \\
\text { tural capital }\end{array}$ & & & & & & & 0.03 & 0.49 & 0.02 & 0.57 \\
\hline $\begin{array}{l}\text { Implies enrolling } \\
\text { into } \mathrm{HE}^{* *}\end{array}$ & & & & & & & & & 0.19 & 0.00 \\
\hline $\begin{array}{l}\text { Implies not enroll- } \\
\text { ing into HE }\end{array}$ & & & & & & & & & -0.03 & 0.48 \\
\hline $\begin{array}{l}\text { Students' embod- } \\
\text { ied cultural capital }\end{array}$ & & & & & & & & & -0.01 & 0.89 \\
\hline
\end{tabular}




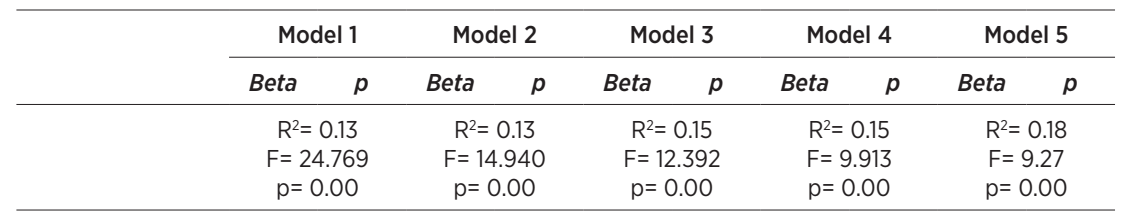

* Referent category: 'Gymnasium'

** $\mathrm{HE}=$ higher education. Referent category: 'Does not imply either outcome'

Analyses indicated that cultural capital and SES variables explain between $13 \%$ and $18 \%$ of the variance of the school achievement. In the first model, female gender was positively associated with achievement, as well as attending gymnasium in relation to vocational schools. In the second model, the variables of parents' education were not significantly associated with school achievement. In the third model, family SES and students' material cultural capital variables were added. The latter was a significant predictor (family SES was not). The introduction of the material dimension somewhat reduced the coefficients of the school type, although they remained statistically significant (Beta coefficient for the three-year school has decreased by about $9 \%$, and for a fouryear school by $15 \%$ ). The third model explained an additional $2 \%$ of the variance criteria (from $13 \%$ to $15 \%$ in total). In the fourth model, variables of relational dimensions of cultural capital were added, i.e. parents' cultural practices and the transmission of cultural capital. These predictors were not statistically significant, and the contribution of previously significant predictors remained the same. In the last model, the variable 'implies the enrolment into HE' was statistically significant predictor for school achievement, while the variable of embodied cultural capital was not. The fifth model explained an additional 3\% of the variance in comparison to the fourth model, and all variables explained $18 \%$ of the variance of the school achievement of students.

Table 3 presents the results of a binary logistic analysis showing the probability of students' decision to enrol into polytechnic schools. 
Table 3. Logit model for predicting probability of enrolment into polytechnic school (referent category: 'probably will/definitely will' enrol into polytechnic school)

\begin{tabular}{|c|c|c|c|c|c|}
\hline \multirow{2}{*}{$(n=493)$} & \multirow{2}{*}{ B } & \multirow{2}{*}{ S.E. } & \multirow{2}{*}{ OR } & \multicolumn{2}{|c|}{ 95\% C.I. OR } \\
\hline & & & & Min. & Max. \\
\hline Gender $(0=M, 1=F)$ & -0.31 & 0.24 & 0.73 & 0.46 & 1.19 \\
\hline \multicolumn{6}{|l|}{ School type } \\
\hline Gymnasium (referent) & 0 & & 1 & & \\
\hline 3-year vocational school & 0.72 & 0.43 & 2.06 & 0.88 & 4.83 \\
\hline 4-year vocational school & 1.36 & 0.30 & $3.90^{* *}$ & 2.18 & 6.97 \\
\hline Father's education & -0.03 & 0.12 & 0.97 & 0.77 & 1.22 \\
\hline Family SES & 0.00 & 0.01 & 1.00 & 0.99 & 1.01 \\
\hline Students' material cultural capital & 0.12 & 0.05 & $1.13^{*}$ & 1.02 & 1.25 \\
\hline Parents' cultural capital & -0.04 & 0.03 & 0.96 & 0.90 & 1.03 \\
\hline \multicolumn{6}{|l|}{ Naturalness of higher education } \\
\hline Implies the enrolment into HE (referent) & 0 & & 1 & & \\
\hline Implies not to enrol into HE & -1.94 & 0.79 & $0.14^{*}$ & 0.03 & 0.68 \\
\hline Does not imply neither outcome & -1.04 & 0.32 & $0.35^{* *}$ & 0.19 & 0.66 \\
\hline Students' embodied cultural capital & 0.04 & 0.03 & 1.04 & 0.99 & 1.09 \\
\hline School achievement & -0.60 & 0.21 & $0.55^{*}$ & 0.37 & 0.83 \\
\hline Constant & -0.76 & 1.06 & 0.47 & & \\
\hline
\end{tabular}

Polytechnic schools in Croatia are traditionally associated with lower prestige than university study. Therefore, whether students from various cultural and socio-economic backgrounds differ with regard to the distinction between the two types of institutions was analysed. ${ }^{5}$ In this model, statistically significant predictors, controlling for the other variables, were the school type, students' material cultural capital, naturalness of higher education and school achievement. Students who attend four-year vocational schools were almost four times more likely to express the intention of enrolling into polytechnics then students who attend gymnasiums. The material dimension of cultural capital was also positively correlated with the intention of continuing their education at the polytechnics. School achievement was significantly and negatively associated with the intention of enrolling into polytechnics: a reduction of one unit value of school achievement increased a chance for intention of continuing education at a polytechnic by $45 \%$.

5 Due to the insignificant correlation with the dependent variable, the variable transmission of cultural capital was excluded from the analysis. Furthermore, mother's education was not included in logistic regression analyses because father's education had stronger correlations with the dependent variables. 
Table 4 presents the results of the multinomial logistic regression for the probability of students' intention of enrolment into university, using the same independent variables as for prediction of intention of enrolment into polytechnics.

Table 4. Logit model for predicting probability of enrolment into university (referent category: 'definitely will' continue education at the university)

\begin{tabular}{lcc}
\hline & $\begin{array}{c}\text { Definitely not/probably not/ } \\
\text { I am not sure }(n=135)\end{array}$ & $\begin{array}{c}\text { Probably will } \\
(n=111)\end{array}$ \\
\cline { 2 - 3 } & $A O R(95 \% \mathrm{Cl})$ & $A O R(95 \% \mathrm{Cl})$ \\
\hline Gender = M & $0.80(0.42-1.53)$ & $1.26(0.73-2.20)$ \\
3-year vocational school & $36.25(10.60-124.00)$ & $4.01(1.51-10.61)^{* *}$ \\
4-year vocational school & $5.08(1.81-14.26)$ & $1.73(0.95-3.16)^{*}$ \\
\hline Gymnasium & 1 & 1 \\
Father's education & $0.74(0.53-1.02)$ & $0.77(0.59-1.00)^{*}$ \\
Family SES & $1.01(0.99-1.02)$ & $1.01(1.00-1.03)$ \\
Students' material cultural capital & $0.94(0.83-1.08)$ & $0.95(0.84-1.06)$ \\
Parents' cultural capital & $0.92(0.84-1.01)$ & $0.94(0.87-1.02)$ \\
Implies the enrolment into HE & $0.09(0.04-0.19)$ & $0.15(0.07-0.31)^{* *}$ \\
Implies not to enrol into HE & $0.70(0.13-3.87)$ & $0.00(0.00-0.00)$ \\
\hline Does not imply neither outcome for enrolment into HE & 1 & 1 \\
Students' embodied cultural capital & $0.89(0.83-0.96)^{* *}$ & $0.92(0.86-0.98)^{* *}$ \\
School achievement & $0.27(0.16-0.48)^{* *}$ & $0.37(0.23-0.59)^{* *}$ \\
\hline *p< 0.05; ** $p<0.01$ & & \\
AOR = odds ratio corrected for the contribution of other independent variables in the model &
\end{tabular}

Statistically significant predictors, with control of other variables in the model, were students' embodied cultural capital, school achievement, type of high school, father's education, and naturalness of higher education. With an increase of one unit of students' embodied cultural capital, the students were $11 \%$ less likely to respond 'definitely not/probably not/not sure' in relation to the answer 'definitely will', for the intention of continuing to university. School achievement was also negatively associated with selecting the answer 'definitely not/probably not/not sure' in relation to the answer 'definitely will'. A reduction of the unit value of the variable school achievement increased the chance to answer 'definitely not/probably not/not sure' in relation to the answer 'definitely will' by $73 \%$. Students of vocational schools were more likely than gymnasium students to answer that they would not try to continue their education at university (or are not sure of it), controlling for the other predictors in the model. 
For students attending three-year vocational schools, a chance for that answer is 36 times higher than for the gymnasium students, and for students of fouryear vocational school about five times higher. Students who find it natural to continue to higher education have a greater probability of answering that they will probably continue to university than students who do not infer any outcome. Furthermore, a reduction of unit value for the variable father's education by $23 \%$ increased the chance of the answer 'probably will' in relation to the answer 'definitely want' (to continue education at university), controlling for other variables.

\section{Discussion}

Multiple regression analysis showed that the material dimension of cultural capital and the naturalness of higher education, as an expression of a specific family habitus, were associated with school achievement. Therefore, it can be concluded that Hypothesis 1 was confirmed. It should be noted that the hypothesis was confirmed only partially, because not all indicators of cultural capital were significant predictors. A conceptually more important dimension, students' embodied cultural capital, was not a significant predictor of overall school achievement, nor was parents' education. Therefore, the confirmation of the hypothesis should be taken with caution, because the material dimension of cultural capital can indicate the level of economic capital. Based on this finding, it seems that the family's material circumstances affected the students' school achievement more than the relational dimension of cultural capital did. This may be due to the fact that material resources can quickly be converted into knowledge (investing in private tutorship/course to enhance knowledge gained in schools), whereas the transmission of cultural capital at home, besides being time-consuming, depends on levels of cultural capital of the parents and their will and ability to help children with school tasks. Moreover, it may be assumed that the students with higher school achievement need their parents' help in school tasks less. However, one of the study limitations is the relatively modest number of indicators of the transfer of cultural capital, so this finding should be taken with caution. Numerous studies (DiMaggio, 1982; De Graaf, 1986, 1988; De Graaf et al., 2000; Flere et al. 2010; Kalmijn and Kraaykamp, 1996; Kingston, 2001; Sullivan, 2000) confirm that the possession of cultural capital is associated with higher educational success; the findings obtained are only partially in accordance with the relevant findings of similar studies.

Logistic regression analysis for the decision to continue education at polytechnic school showed that the higher possession of cultural resources 
(material cultural capital) was positively correlated with the intention of enrolling into polytechnics and negatively with school achievement. Thus, Hypothesis 3 is partially confirmed; the material cultural capital being significant predictor, but not the embodied forms of cultural capital. Polytechnics in Croatia are mainly private institutions; hence the finding that the material dimension of cultural capital affects the likelihood of intention of enrolling into polytechnics was expected. In accordance with these findings, it would be logical to expect that the family's SES was a significant predictor of enrolment into polytechnics; however, it was not significant in the analysis. One possible interpretation is that the polytechnic education attracts children who do not have high school achievement, but their parents have certain material conditions or possess cultural capital that encourages them to acquire at least a polytechnic higher education qualifications, while families with high SES but not the material dimension of cultural capital, do not insist on obtaining higher education qualifications.

The analysis of the decision to continue high school education at university indicated that the significant and positive predictors of the likelihood of expressing the intention of enrolling in university were students' embodied cultural capital, father's education, school type (gymnasium), school achievement, and the naturalness of higher education for students. The significance of important predictors of cultural capital indicated that Hypothesis 2 was confirmed. These results may indicate that the high school differentiation of 'cultural capital light' and 'cultural capital heavy' institutions (Jæger, 2009, p. 1951) can be applied to the university and polytechnic education (for the decision on enrolling into polytechnic institutions, the parents' cultural capital was not significant, nor was students' embodied cultural capital), as a new form of maintaining social distance between different social classes. Since the educational expansion of tertiary education has enabled the influx of a large number of students from all social strata (although not in equal proportions), the differentiation of classes has changed in the qualitative distinction between types of higher education institutions and fields of study (Bourdieu, 1984). Van de Werfhorst, Sullivan and Cheung (2003) have shown that students from upper-class families more often chose prestigious higher education fields than the children of unskilled manual workers did.

Overall, it can be considered that the results of this study on a selected sample of graduates tend to support the evidence of previous findings based on Bourdieu's theory of cultural reproduction. Students from privileged social backgrounds tend to have better educational achievement than their peers from less privileged backgrounds do, and more frequently have aspirations to 
continue their education at the university. Although it would be necessary to analyse the entire educational and professional path of the students and their parents to confirm the maintenance of social inequality through education, it could be considered that these study results tend to support the reproduction thesis for the selected population of students.

\section{Acknowledgement}

I am thankful to my friends and colleagues Aleksandar Štulhofer and Margareta Gregurović for their comments and thoughts on the statistical analyses on which I based this text.

\section{References}

Babarović, T., Burušić, J., \& Šakić, M. (2009). Uspješnost predviđanja obrazovnih postignuća učenika osnovnih škola Republike Hrvatske [Prediction of Educational Achievements of Primary School Pupils in the Republic of Croatia]. Društvena istraživanja, 18(4-5/102-103), 673-95.

Baranović, B. (2015). Razvoj i socijalna dimenzija visokog obrazovanja u Hrvatskoj [Development and Social Dimension of Higher Education in Croatia]. In B. Baranović (Ed.), Koji srednjoškolci namjeravaju studirati? Pristup visokom obrazovanju i odabir studija [Who Plans to Study? - Higher Education Access and Course Choice] (pp. 15-41). Zagreb: Institut za društvena istraživanja u Zagrebu.

Barone, C. (2006). Cultural Capital, Ambition and the Explanation of Inequalities in Learning Outcomes: A Comparative Analysis. Sociology - the Journal of the British Sociological Association, 40(6), 1039-1058.

Bourdieu, P. (1973). Cultural Reproduction and Social Reproduction. In R. Brown (Ed.), Knowledge, Education, and Cultural Change (pp. 71-84). London: Tavistock.

Bourdieu P. (1977a). Cultural Reproduction and Social Reproduction. In J. Karabel \& A. H. Halsey (Eds.), Power and Ideology in Education (pp. 487-511). New York: Oxford University Press. Bourdieu P. (1977b). Outline of a Theory of Practice. Cambridge: Cambridge University Press. Bourdieu, P. (1984). Distinction: A Social Critique of the Judgement of Taste. London: Routledge. Bourdieu, P. (1986). The Forms of Capital, 1997 (1986). In J. E. Richardson (Ed.), Handbook of Theory of Research for the Sociology of Education (pp. 241-258). New York: Greenword Press. Bourdieu, P. (1989). Social Space and Symbolic Power. Sociological Theory, 7(1), 14-25. Bourdieu, P. (1990). Outline of a Theory of Practice. Cambridge: Cambridge University Press. Burušić, J., Babarović, T., \& Marković, N. (2010). Koliko daleko padaju jabuke od stabla? Odnos obrazovnih postignuća djece i obrazovne razine njihovih roditelja [How Far Does the Apple Fall from the Tree? The Relationship between Childrens Educational Achievement and the Educational Level of their Parents]. Društvena istraživanja, 19(4-5/108-109), 709-730. 
Croatian Bureau of Statistics - Census (2011). Retrieved 20. 1. 2015 from www.dzs.hr.

De Graaf, N. D., De Graaf, P. M., \& Kraaykamp, G. (2000). Parental Cultural Capital and Educational Attainment in the Netherlands: A Refinement of the Cultural Capital Perspective. Sociology of Education, 73(2), 92-111.

De Graaf, P. M. (1986). The Impact of Financial and Cultural Resources on Educational Attainment in the Netherlands. Sociology of Education 59(4), 237-246.

DiMaggio, P. (1982). Cultural Capital and School Success: The Impact of Status Culture Participation on the Grades of U.S. High School Students. American Sociological Review, 47(2), 189-201.

Doolan, K. (2009). 'My Dad Studied Here Too': Social Inequalities and Educational (Dis)advantage in a Croatian Higher Education Setting (Doctoral dissertation). University of Cambridge.

Downey, D. B. (1995). When Bigger is not Better: Family Size, Parental Resources, and Children's Educational Performance. American Sociological Review 60(5), 746-759.

Dumais, S. A. (2006). Early Childhood Cultural Capital, Parental Habitus, and Teachers' Perceptions. Poetics, 34(1), 83-107.

Erikson, R., Goldthorpe, J. H., Jackson, M., Yaish, M., \& Cox, D. R. (2005). On class differentials in educational attainment. Retrieved 22. 1. 2015 from http://www.pnas.org/content/102/27/9730.full. Erikson, R. (2007). Social Selection in Stockholm Schools: Primary and Secondary Effects on the Transition to Upper Secondary Education. In S. Scherer, R. Pollak, G. Otte \& M. Gangl (Eds.), From Origin to Destination: Trends And Mechanisms In Social Stratification Research (pp. 35-76). Frankfurt: Campus Verlag.

Eurostat (2013). Intergenerational transmission of disadvantage statistics. Retrieved 15. 1. 2015 from http://ec.europa.eu/eurostat/statistics-explained/index.php/Intergenerational_transmission_of_ disadvantage_statistics.

Flere, S., Tavčar Krajnc, M., Klanjšek, R., Musil, B., \& Kirbiš, A. (2010). Cultural Capital and Intellectual Ability as Predictors of Scholastic Achievement: a Study of Slovenian Secondary School Students. British Journal of Sociology of Education 31(1), 47-58.

Goldthorpe, J. H. (2007). Cultural Capital: Some Critical Observations. Sociology Working Papers. University of Oxford. Retrieved 21. 5. 2014 from http://www.sociology.ox.ac.uk/materials/papers/ swpo7_07.pdf.

Gregurović, M., \& Kuti, S. (2010). Učinak socioekonomskog statusa na obrazovno postignuće učenika: Primjer PISA istraživanja, Hrvatska 2006 [Effect of Socioeconomic Status on Students' Educational Achievement: The Example of Pisa Study, Croatia 2006]. Revija za socijalnu politiku, $17(2), 179-96$.

Guri-Rosenblit, S, Sebkova H., \& Teichler U. (2007). Massification and Diversity of Higher Education Systems: Interplay of Complex Dimensions. Retrieved 10. 11. 2014 from http://portal.unesco.org/ education/en/files/53906/11858770845Massification_diversification.pdf/Massification_diversification. pdf.

Jæger, M. M. (2009). Equal Access but Unequal Outcomes: Cultural Capital and Educational Choice in a Meritocratic Society. Social Forces 87(4), 1943-1971. 
Jæger, M. M. (2011). A Dynamic Model of Cultural Reproduction. Retrieved 20. 5. 2015 from http:// www.sofi.su.se/polopoly_fs/1.65120.1323949644!/Mads_Meier_Jaeger_20111208.pdf. Jokić, B., \& Ristić Dedić, Z. (2010). Razlike u školskom uspjehu učenika trećih i sedmih razreda osnovnih škola u Republici Hrvatskoj s obzirom na spol učenika i obrazovanje roditelja: populacijska perspektiva [Differences in Educational Attainment of Third and Seventh Grade Pupils in Croatia with Respect to Gender and Parents' Educational Level: A Population Perspective]. Revija za socijalnu politiku, 17(3), 345-362.

Kalmijn, M., \& Kraaykamp, G. (1996). Race, Cultural Capital, and Schooling: An Analysis of Trends in the United States. Sociology of education, 69(1), 22-34.

Karabel, J., \& Halsey, A. H. (Ed.) (1977). Power and Ideology in Education. New York: Oxford University Press.

Kingston, P. W. (2001). The Unfulfilled Promise of Cultural Capital Theory. Sociology of Education 74(Extra Issue), 88-99.

Lareau, A., \& Horvat, E. M. (1999). Moments of Social Inclusion and Exclusion. Sociology of Education, 72, 37-53.

Lareau, A., \& Weininger, E. B. (2003). Cultural Capital in Educational Research: A Critical Assessment. Theory and Society 32(5/6), 567-606.

Matković, T. (2010). Obrazovanje roditelja, materijalni status i rano napuštanje školovanja u Hrvatskoj: trendovi u proteklom desetljeću [Parental Education, Income Level and Early School Leaving in Croatia: Trends of the Last Decade]. Društvena istraživanja, 19(4-5/108 -109), 643-667. OECD (2010). A Family Affair: Intergenerational Social Mobility across OECD Countries. Retrieved 11. 3. 2014 from http://www.oecd.org/tax/public-finance/chapter\%205\%20gfg\%202010.pdf.

Puzić, S., Gregurović, M., \& Košutić, I. (2016). Cultural Capital - A Shift in Perspective: An Analysis of PISA 2009 Data for Croatia. British Journal of Sociology of Education, 37(7), 1056-1076.

Puzić, S., Doolan, K., \& Dolenec, D. (2006). Socijalna dimenzija 'Bolonjskog procesa' i (ne)jednakost šansi za visoko obrazovanje: neka hrvatska iskustva [Social Dimension of the Bologna Process and (Un)Equality of Chances of Getting High Education: Some Croatian Experiences]. Sociologija sela, 44(172-173/2-3), 243-6o.

Strategy of Science, Education and Technology (2014). Retrieved 10. 2. 2015 from http://narodnenovine.nn.hr/clanci/sluzbeni/2014_10_124_2364.html.

Sullivan, A. (200o). Cultural Capital, Rational Choice, and Educational Inequalities (Doctoral Dissertation). Oxford: Oxford University.

Swartz, D. (1997). Culture and Power. The Sociology of Pierre Bourdieu. Chicago: The University of Chicago Press.

Teachman, J. D. (1987). Family Background, Educational Resources and Educational Attainment. American Sociological Review, 52(4), 548-557.

Tramonte, L., \& Willms, J. D. (2010). Cultural capital and its effects on education outcome. Economics of Education Review, 29(2), 200-213.

Trow, M. (1974). Problems in the Transition from Elite to Mass Higher Education. Carnegie 
Commission on Higher Education Berkeley, Berkeley, California. Retrieved 15. 7. 2014 from http:// files.eric.ed.gov/fulltext/EDo91983.pdf.

The Universal Declaration on Human Rights, United Nations (1948). Retrieved 15. 7. 2014 from http:// www.un.org/en/universal-declaration-human-rights/index.html.

Van de Werfhorst, H. G., Sullivan, A., \& Cheung S.Y. (2003). Social class, ability and choice of subject in secondary and tertiary education in Britain. British Educational Research Journal 29(1), 41-62.

Weber, M. (1968). Economy and Society. New York: Bedminster Press.

\section{Biographical note}

Iva Košutić, $\mathrm{PhD}$, is a postdoctoral fellow at the Institute for Social Research - Zagreb, Centre for Educational Research and Development. She received her $\mathrm{PhD}$ in sociology in 2015 at the Faculty of Humanities and Social Sciences, University of Zagreb. Her fields of interest include sociology of education, with the emphasis on social dimension of higher education. She has research experience in the field of education; her research projects so far included various topics - the quality of compulsory education, the social dimension of secondary education, financing of the higher education, equity in higher education, higher education/study choice. 